\title{
News from the Field
}

\section{Rocky Mountain College dedicates new library}

The Paul M. Adams Library at Rocky Mountain College in Billings, Montana, has doubled in size to 28,000 square feet with the opening of the new Educational Resource Center (ERC). The $\$ 4.2$ million project began in April 1998 and was completed in June 1999. ERC contains three computer labs, a distance education center, three archival collections, spacious work areas, and numerous individual study carrels and group study areas. A large endowment will be used to keep the 70,000 -volume collection up-to-date. DG Architects of Billings served as the architects in charge of the project.

\section{WESS represents ACRL at Frankfort Book Fair}

Promoting intemational relations and the exchange of ideas, the ACRL Board of Directors accepted an invitation from the International Booksellers and Librarians Center to send representatives from the Western European Specialists Section (WESS) to attend the 51st Frankfurt Book Fair on October 13-18, 1999. After receiving a champagne welcome from U.S. Ambassador John Kornblum the day before, the WESS team presented a total of seven papers in three languages on topics ranging from resource sharing and faculty-librarian relations at U.S. academic libraries to fundraising and issues of translation. WESS's full report on the Frankfurt Book Fair can be found at the WESS Web site WESSweb at http://www.lib. virginia.edu/wess/.

\section{Old Dominion}

\section{celebrates 22nd annual} Literary Festival

Old Dominion University (ODU) celebrated its 22nd Annual Literary Festival this fall. Using the theme, "The Spirit of the Word," the festival featured Rita Dove, former poet laureate of the United
States, and many other regionally and nationally recognized poets and writers. The full history of the 22 festivals is being documented on ODU's Web site and should be completed

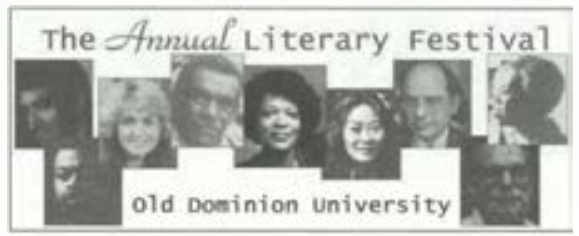

by October 2000 . The work in progress can be viewed at http://www.lib.odu.edu.litfest.

\section{Be a winner! Visit the ACRL booth in San Antonio}

Stop by booth $\# 266$ at the ALA Midwinter Meeting in San Antonio. Learn more about ACRL programs and activities and pick up information about Denver, site of ACRL's 10th National Conference, March 15-18, 2001. Enter a raffle to win souvenirs of Denver!

\section{Bowling Green designates librarian for freshmen}

To help students overcome their anxiety and become more proficient at using the library,

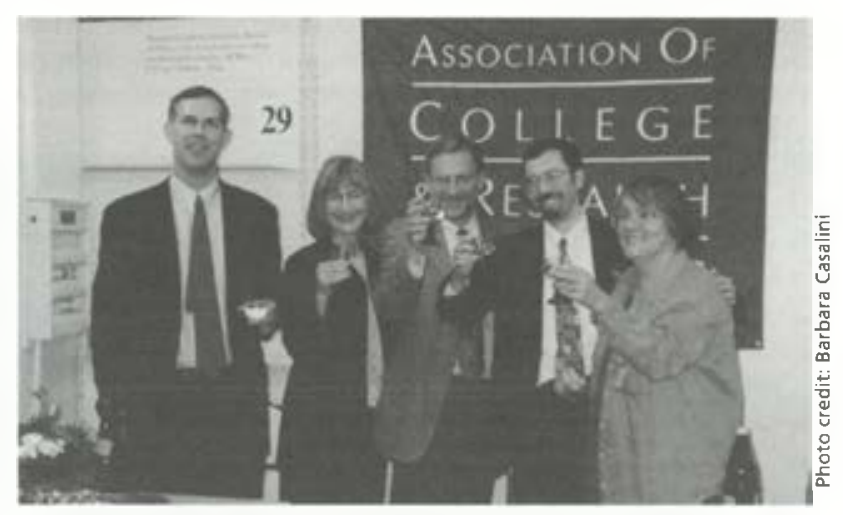

Members of ACRL's Western European Specialists Section celebrate the end of "USA Day" at the International Booksellers and Librarians Center of the Frankfurt Book Fair on Saturday, October 16. Pictured (I to r) are: Michael Olson (Harvard), Marcia Pankake (University of Minnesota), Jeff Garrett (Northwestern), Jim Niessen (Texas Tech), and Barbara Walden (University of WisconsinMadison) 


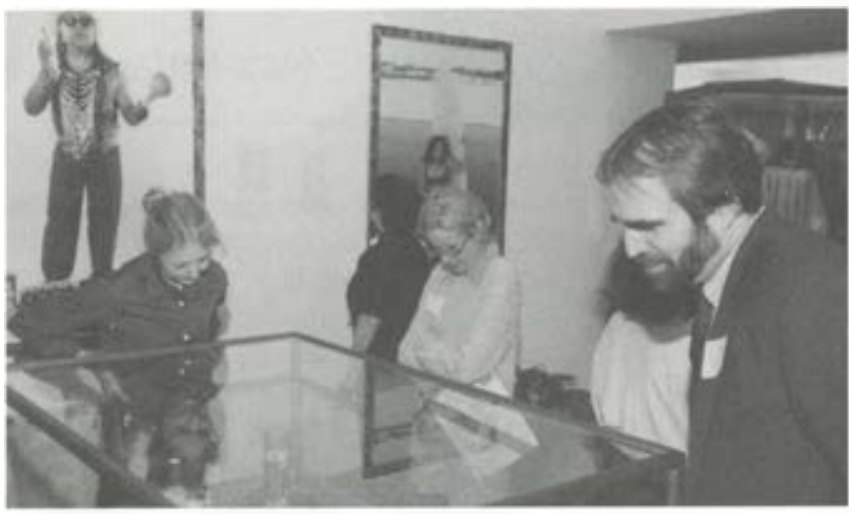

Visitors enjoy the special exhibition by Native American artist James Luna installed at the Tozzer Library, the anthropology library of the Harvard College Library, to celebrate its 25th anniversary as a freestanding library. Tozzer Library traces its history back to the 1866 founding of the Peabody Museum of Archaeology and Ethnology. Until 1974, when the library moved into its own building, it was known as the Peabody Museum Library and was an integral part of the museum. Tozzer Library is now an administrative part of the Harvard College library and houses one of the world's foremost collections in anthropology and its subfields.
Attend hearing on

professional development

ACRL's Professional Development Committee has drafted a statement on professional development for academic and research librarians. Hearings on the draft document will be held at the ALA Midwinter meeting in San Antonio on Sunday, January 16 , from 4:30-5:30 p.m. The document is posted on the ACRL Web site at http:// www.ala.org/acrl/. Comments on the statement may be sent to the committee chair Lee Van Ordsel at libvanor@acs. eku.edu.
Bowling Green State University (BGSU) has designated one of its librarians to be a "firstyear experience" librarian.

Collen Boff, hired last spring to fill the new position, has been busy this fall conducting library tours and teaching sessions for the 33 sections of BGSU's University Success courses, which are designed to help students make a successful transition from high school to college.

"With first-year students, their personal touch is really important," said Linda Dobb, one of the originators of the idea who is now interim provost at BGSU and formerly dean of the libraries and learning resources there.

"We've found that when students have had a successful experience with a librarian, it brings them back again and again."

When the job was announced, John Gardner, founder of the National Resource Center for the First-year Experience and Stuclents in Transition at the University of South Carolina, sent BGSU a congratulatory note.

"This, I believe, is precedent-setting," Gardner wrote, adding, "I hope many other institutions will emulate you in setting up such a role."

\section{Univ. of Calgary opens Information Commons}

The University of Calgary opened its new Information Commons in time for the fall semester. The Information Commons integrates the library information services and university computing services, providing an easy way for clients to get both information and technology questions answered. Three public service access points are available in the commons, as well as 260 computers with access to the Internet, e-mail, electronic research resources, and office productivity software. Fifty of the computers are located in a large instruction

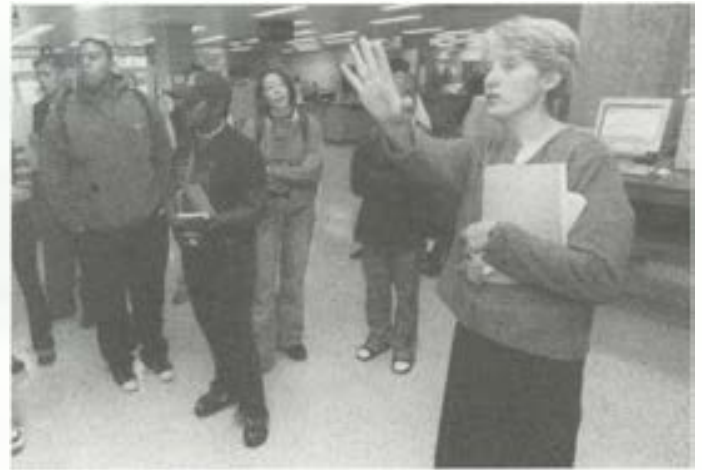

Collen Boff, Bowling Green State University's (BGSU) first "first-year experience librarian," gives a tour of the library to some BGSU freshmen. 


\section{2 signs that you have had too much of the '90s . .}

This little ditty made us smile and we hope you will enjoy it as we wind down the 1990s!

1. You tried to enter your password on the microwave.

2. You now think of three expressos as "getting wasted."

3. You haven't played solitaire with a real deck of cards in years.

4. You have a list of 15 phone numbers to reach your family of 3 .

5.You e-mail your son in his room to tell him that dinner is ready, and he e-mails you back "What's for dinner?"

6. Your daughter sells Girl Scout Cookies via her Web site.

7. You chat several times a day with a stranger from South Africa, but you haven't spoken with your neighbor yet this year.

8. You didn't give your valentine a card this year, but you posted one for your email buddies via a Web page.

9.Your daughter just bought a CD of all the records your college roommate used to play.

10. You check the ingredients on a can of chicken noodle soup to see if it contains Echinacea.

11. You check your blow dryer to see if it's Y2K compliant.

12. Your grandmother clogs up your email inbox asking you to send her a JPEG file of your newborn so she can create a screen saver.
13. You pull up in your own driveway and use your cell phone to see if anyone is home.

14.Every commercial on television has a Web site address at the bottom of the screen.

15. You buy a computer and a week later it is out of date and now sells for half the price you paid.

16. The concept of using real money, instead of credit or debit, to make a purchase is foreign to you.

17. Cleaning up the dining area means getting the fast food bags out of the back seat of your car.

18. Your reason for not staying in touch with family is that they do not have e-mail addresses.

19. You consider 2 nd day air delivery painfully slow.

20. You refer to your dining room table as the flat filing cabinet.

21. Your idea of being organized is multiple colored Post-it ${ }^{\circledR}$ notes.

22. You hear most of your jokes via email instead of in person.

-Reprinted with permission from the UCR (University of California, Riverside) Library News, vol. 26, no. 9, Sept. 27, 1999 area; six additional ones serve a small group instruction area. Twenty-five to thirty computers are designated express stations giving library clients quick and easy access to information held by the library.

\section{C\&RL News seeks column editor}

CERL News is looking for a column editor for a new "Fast Facts" column. The column will be a smorgasbord of economic and demographic facts, statistics, quotable quotes, and other tidbits of interest to our readers. Those interested in applying should send an e-mail to editor Mary Ellen Davis (medavis@ala.org) outlining their interest, experience, and some sample fast facts by January 7, 2000. Selected applicants may be invited to meet with the CERL News Editorial Board at the Midwinter Meeting.

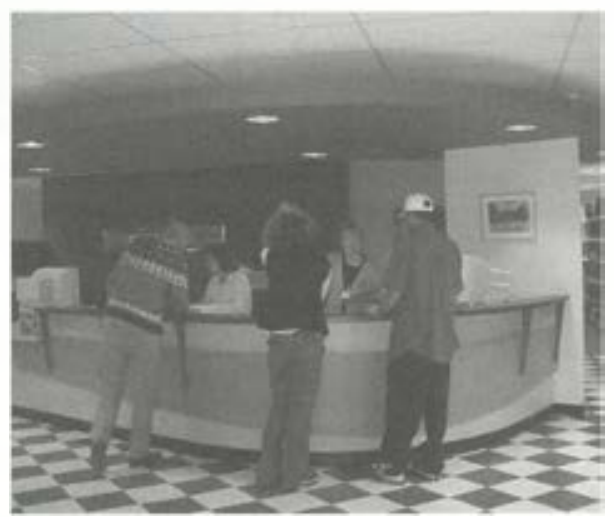

One of the service desks at the University of Calgary's new Information Commons, which includes 260 workstations. 


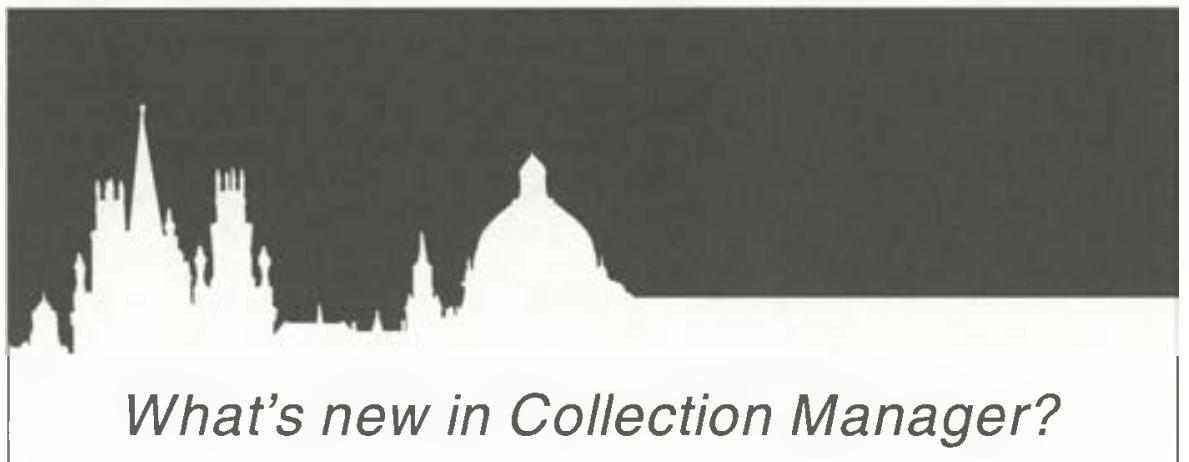

The world's best web-based collection management tool has just gotten better. Collection Manager, from Blackwell's Book Services, now offers you the most advanced features in the industry. . .

\title{
Streamlined search screens \\ Expanded online help \\ More onscreen narrative instructions \\ Downloadable reference sheets \\ Efficient, one-click ordering
}

Support for multiple orders and orders for titles not in the database Ability to ensure inclusion of specified titles in approval shipments Coming soon, customized lists that can be saved, reviewed and edited

All these features, plus Tables of Contents for current year's titles, combine to guarantee that your collection development decisions are informed by the most authoritative information available.

\section{Collection Manafer}

For more information contact...

\section{BLACKWELL'S \\ BOOK SERVICES}

\author{
Maggie McNair \\ 6024 SW Jean Road, Building G \\ Lake Oswego, Oregon 97035 \\ Telephone: 1-800-547-6426 \\ E-mail: mktg@blackwell.com \\ Internet: http://www.blackwell.com
}

Oxford - Lake Oswego - Blackwood S Sydney 